\title{
Evaluation of Warm-season
}

\section{Turfgrasses for Resistance to the Chinch Bug, Blissus occiduus}

\author{
Thomas E. Eickhoff ${ }^{1}$, Tiffany M. Heng-Moss, and \\ Frederick P. Baxendale \\ Department of Entomology, University of Nebraska-Lincoln, 202 Plant \\ Industry Building, Lincoln, NE 68583-0816
}

Additional index words. bermudagrass, buffalograss, zoysiagrass, plant resistance, IPM, integrated pest management, plant breeding

\begin{abstract}
The chinch bug, Blissus occiduus Barber, has been documented as a serious pest of buffalograss, Buchloë dactyloides (Nutall) Engelmann, and zoysiagrass, Zoysia japonica Steudel, turf grown in the Midwest. In addition to these two warm-season turfgrasses, several other warm-season grasses, including bermudagrass, Cynodon dactylon (L.) Pers., may also be at risk of $B$. occiduus infestations. This research evaluated selected bermudagrass and zoysiagrass cultivars for resistance to $B$. occiduus. Eleven zoysiagrass and four bermudagrass cultivars were evaluated for resistance to $B$. occiduus using no-choice studies under greenhouse conditions. Based on turfgrass damage ratings, the zoysiagrasses 'Diamond', 'Zoro', and 'Emerald', and bermudagrass 'Mini Verde' were identified as moderately resistant to $B$. occiduus. The zoysiagrasses 'Zenith', 'Meyer', and 'Crowne', and bermudagrasses 'Tifway 419' and 'Tifsport' were characterized as highly to moderately susceptible to $B$. occiduus. These results provide the first report of resistance to $B$. occiduus in zoysiagrass and bermudagrass germplasm.
\end{abstract}

The western chinch bug, Blissus occiduus Barber, is one of four chinch bug species commonly associated with turfgrasses in the United States. In addition to B. occiduus, the common chinch bug [Blissus leucopterus leucopterus (Say)], the hairy chinch bug (Blissus leucopterus hirtus Montandon), and the southern chinch bug (Blissus insularis Barber) are considered serious turfgrass pests. These four chinch bug species are part of a chinch bug complex that have a wide distribution extending primarily east of the Rocky Mountains and from Mexico to Canada (Vittum et al., 1999), and have a well-documented host range that encompasses many economically important crop, weed, and turfgrass species. The hairy chinch bug is found primarily in the northeastern United States and is normally associated with cool-season turfgrasses, whereas southern chinch bugs occur in southern areas of the United States and feed on warm-season turfgrasses (Reinert et al., 1995).

\footnotetext{
Received for publication 5 Oct. 2006. Accepted for publication 9 Dec. 2006.

A contribution of the University of Nebraska Agricultural Research Division, supported in part by funds provided through University of Nebraska Agricultural Expt. Sta. project 17-062. Additional support was provided by the United States Golf Association and the Nebraska Turfgrass Association. We gratefully acknowledge Bob Wright and Tom Hunt for reviewing the manuscript, and Mitch Stamm, Travis Prochaska, and Chelsey Wasem (University of Nebraska) for technical assistance.

${ }^{1}$ To whom reprint requests should be addressed; e-mailTEICKHOFF2@unl.edu
}

Blissus occiduus has a reported distribution, including Arizona, California, Colorado, Kansas, Montana, Nebraska, New Mexico, and Oklahoma in the United States; and Alberta, British Columbia, Manitoba, and Saskatchewan in Canada (Baxendale et al., 1999; Bird and Mitchner, 1950; Slater, 1964). This chinch bug's host range includes numerous agriculturally and horticulturally important crop, weed, and turfgrass species (Bird and Mitchner, 1950; Eickhoff et al., 2004; Farstad and Staff, 1951; Ferris, 1920). Although the original report of $B$. occiduus as a turfgrass pest was on buffalograss [Buchloë dactyloides (Nutall) Engelmann], (Baxendale et al., 1999) it has since emerged as a serious pest of zoysiagrass (Zoysia japonica Steudel) turf in areas of southeastern Nebraska (Eickhoff et al., 2006). The growing popularity of buffalograss as a low-maintenance turfgrass requiring reduced levels of irrigation, nitrogen, and mowing (Frank et al., 2004) has dramatically increased the amount of buffalograss planted in newly developed areas, including southern regions of the United States. As these buffalograss stands experience chinch bug damage, B. occiduus will likely seek out secondary hosts in close proximity, such as bermudagrass [Cynodon dactylon (L.) Pers.] and zoysiagrass. Furthermore, research by Eickhoff et al. (2006) indicates that of $B$. occiduus documented grass hosts, the warm-season turfgrasses bermudagrass, buffalograss, and zoysiagrass are at highest risk of serious damage.

Currently, insecticides are available that will effectively control chinch bugs in turfgrass. However, with growing concern over the effects of pesticide use in urban areas and the potential for the development of resistance to insecticides, the identification of plants with resistance offers an effective and environmentally responsible alternative for managing this pest. Differences in the susceptibility of several cool- and warmseason turfgrasses to chinch bugs have been well documented (Ahmad et al., 1984; Baker et al., 1981; Gulsen et al., 2004; Heng-Moss et al., 2002; Lynch et al., 1987; Mathais et al., 1990; Ratcliffe, 1982; Reinert and Dudeck, 1974). In buffalograss, Heng-Moss et al. (2003) identified the cultivars Cody and Tatanka as tolerant, whereas Prestige exhibited both tolerance and antixenosis to B. occiduus. Further research by Gulsen et al. (2004) identified the buffalograss genotypes '184', '196', and 'PX3-5-1' as highly resistant to $B$. occiduus. Although researchers have identified resistance in bermudagrass and zoysiagrass cultivars to other turfgrass pests, including bermudagrass mites, Eriophyes cynodoniensis Sayed, fall armyworm Spodoptera frugiperda (J.E. Smith), hunting billbug Sphenophorus venatus vestitus Chittenden, and tawny mole cricket Scapteriscus vicinus Scudder (Braman et al., 1994, 2004; Reinert et al., 1993, 2005), very little information is available on the susceptibility of zoysiagrass and bermudagrass germplasm to chinch bugs. The recent emergence of $B$. occiduus as a serious pest of zoysiagrass, and its potential to damage bermudagrass, underscores the need for information regarding the susceptibility of these grasses to this insect pest. Accordingly, the objective of this research was to evaluate selected bermudagrass and zoysiagrass germplasm for resistance to B. occiduus.

\section{Materials and Methods}

Eleven zoysiagrasses and four bermudagrasses were selected and screened under greenhouse conditions to evaluate their resistance to $B$. occiduus. These grasses were selected because they are commercially available and commonly planted. Grasses evaluated included the zoysiagrass cultivars Cavalier, Crowne, DeAnza, Diamond, Emerald, El Toro, Meyer, Palisades, Royal, Zenith, and Zoro, and the bermudagrass cultivars Jackpot, Mini Verde, Tifway 419, and Tifsport. The buffalograsses 'Prestige' and ' 378 ' served as the resistant and susceptible checks respectively in all experiments, because these buffalograsses have documented levels of resistance to B. occiduus.

The zoysiagrasses 'Crowne', 'Emerald', 'El Toro', 'Meyer', and 'Palisades', and the bermudagrasses 'Tifway 419' and 'Mini Verde' were acquired from Turfgrass America (Cleveland, Texas). 'Cavalier', 'Diamond', 'Royal', and 'Zoro' zoysiagrasses were obtained from M.C. Engelke at Texas A\&M University (Dallas, Texas), and 'DeAnza' zoysiagrass and 'Tifsport' bermudagrass were provided by $\mathrm{C}$. Rogers at the University of Arizona (Maricopa, Ariz.). 
'Zenith' zoysiagrass was purchased from Todd Valley Farms (Mead, Nebr.), and stolons of 'Jackpot' bermudagrass were obtained from bermudagrass stands on the University of Nebraska-Lincoln campus. Sod plugs (diameter, $10.6 \mathrm{~cm}$; depth, $8 \mathrm{~cm}$ ) of 'Prestige' and ' 378 ' buffalograss were extracted from research plots at the John Seaton Anderson Turfgrass and Ornamental Research Facility (JSA Research Facility), University of Nebraska Agricultural Research and Development Center, near Mead, Nebr. The previously named grasses were vegetatively established in the greenhouse in $35 \times$ $50-\mathrm{cm}$ flats and provided the vegetative plant material for these experiments.

Before initiation of experiments, turfgrasses were vegetatively propagated by planting individual stolons or rhizomes of each grass in an SC-10 Super Cell Ray Leach Cone-tainer single-cell system (diameter, $3.8 \mathrm{~cm}$; depth, $21 \mathrm{~cm}$; Stuewe \& Sons, Corvallis, Ore.) containing a potting mixture of 2 sand : 1 soil : 3 peat : 3 perlite ratio. Conetainers were placed in $7 \times 14$ Cone-tainer trays (Stuewe \& Sons). Plants were irrigated as needed, fertilized weekly with a soluble $20 \mathrm{~N}-10 \mathrm{P}-20 \mathrm{~K}$ fertilizer, and were maintained under 400-W high-intensity discharge lamps with a $16 \mathrm{~h} / 8 \mathrm{~h}$ (day/night) photoperiod. Grasses were trimmed to the soil surface 1 week before initiation of experiments to ensure that all grass vegetation was about the same age at the onset of the experiment.

Two greenhouse screening studies were conducted using $B$. occiduus collected from buffalograss research plots at the JSA Research Facility by vacuuming the soil surface with a modified ECHO Shred'N Vac (model no. 2400; ECHO Inc., Lake Zurich, Ill.). Chinch bugs were held under laboratory conditions [26 $\pm 3{ }^{\circ} \mathrm{C}, 16: 8$ (light/dark)-h photoperiod] and preconditioned by starving for $24 \mathrm{~h}$ before the initiation of the experiment. A total of 10 fourth and fifth [determined according to Baxendale et al. (1999)] instar chinch bugs (sex undetermined) were collected with an aspirator, placed on plants in Cone-tainers fitted with tubular Plexiglas cages (diameter, $4 \mathrm{~cm}$; height, $30 \mathrm{~cm}$ ), and the tops were covered with organdy fabric. The experimental design for all experiments was a completely randomized design with six replications. Both studies were conducted using second-generation chinch bugs. Studies 1 and 2 were conducted from 16 Sept. to 3 Nov. 2003 and 26 Sept. to 11 Nov. 2003 respectively.

The susceptibility of the turfgrasses to $B$. occiduus feeding was measured by visually rating plants for chinch bug damage every third day. Damage ratings were based on a 5 -point scale, where 1 is $10 \%$ or less of leaf area with reddish discoloration, 2 is $11 \%$ to $30 \%$ of leaf area with reddish discoloration, 3 is $31 \%$ to $50 \%$ of leaf area with reddish discoloration, 4 is $51 \%$ to $70 \%$ of leaf area with reddish or yellowing discoloration, and 5 is $71 \%$ or more of leaf area with severe discoloration or dead tissue (Heng-Moss et al., 2002).
When the mean damage rating of the B. occiduus-susceptible grass (' 378 ') reached 4.0 or more, the contents (soil and grass) of each cone-tainer were placed in a Berlese funnel (Southwood, 1978) for $48 \mathrm{~h}$. Extracted chinch bugs were collected in $70 \%$ ethyl alcohol and counted. Grasses were grouped into one of four levels of susceptibility based on mean chinch bug damage ratings for each study. The four levels were designated as HS (highly susceptible; chinch bug damage rating $\geq 4$ ), MS (moderately susceptible; chinch bug damage rating $\geq 3$ but $<4$ ); MR (moderately resistant; chinch bug damage rating $>1$ but $<3$ ), and HR (highly resistant; chinch bug damage rating $=1$ ) (Anderson et al., 2006; Heng-Moss et al., 2002).

Statistical analysis. Grasses were grouped by species (bermudagrass and zoysiagrass) and data were analyzed using mixed model analysis (PROC MIXED v. 9.1; SAS Institute, Cary, N.C.) to detect differences in $B$. occiduus damage and number of chinch bugs at harvest. Both groups of turfgrass species were compared with the resistant and susceptible buffalograsses. When appropriate, means were separated using Fisher's least significant difference (LSD) procedure.

\section{Results}

Zoysiagrasses. Statistically significant differences (study 1: $\mathrm{F}=9.48$, df $=12,65$, $P=0.0001$; study $2: \mathrm{F}=10.21, \mathrm{df}=11,60$, $P=0.0001)$ in $B$. occiduus damage ratings and the number of $B$. occiduus (study 1 : $\mathrm{F}=6.14$, $\mathrm{df}=12,65, P=0.0001 ;$ study $2: \mathrm{F}=4.75, \mathrm{df}=$ $11,60, P=0.0001)$ remaining on the grasses at harvest were detected among the turfgrass species evaluated in studies 1 and 2 (Table 1). None of the zoysiagrasses tested in studies 1 and 2 had damage ratings as high as the susceptible buffalograss cultivar 378 , which was highly susceptible to chinch bug feeding (mean damage ratings, 4.0 and 4.5 respectively; mean number of chinch bugs, 39.2 and 61.3 respectively). These results support the findings of Heng-Moss et al. (2003), who noted that ' 378 ' is highly susceptible to B. occiduus. The zoysiagrasses 'Meyer', 'Zenith', and 'Crowne' were highly to moderately susceptible to $B$. occiduus feeding, reaching a damage rating of $\geq 4.0$ in at least one of the studies. 'DeAnza' was moderately susceptible, with a mean damage rating of 3.3. 'El Toro', 'Royal', 'Cavalier', and 'Palisades' were moderately resistant to moderately susceptible, with damage ratings ranging between 2.8 and 2.3 in study 1 and from 3.3 to 3.0 in study 2. 'Crowne', 'El Toro', and 'Zenith' had large numbers of B. occiduus $(23.8,36.5$, and 14.5 in study 1 respectively; and $24.5,16.8$, and 11.0 in study 2 respectively) remaining at harvest (Table 1). Conversely, 'Meyer' and 'DeAnza' sustained significant damage from $B$. occiduus despite low numbers of chinch bugs on the plants, suggesting their high level of susceptibility to B. occiduus. 'Diamond', 'Zoro', and 'Emerald' were characterized as moderately resistant and had lower damage ratings (damage ratings between 2.8 and 2.2 in studies 1 and 2 respectively) than the known chinch bug-resistant buffalograss 'Prestige' (ratings of 2.5 and 2.8 respectively), indicating these zoysiagrasses are also resistant to B. occiduus. All the zoysiagrasses characterized as moderately resistant had significantly fewer chinch bugs remaining at harvest than 'Prestige', suggesting the presence of antibiosis or antixenosis; however, further research is needed to confirm this observation.

Bermudagrasses. Statistically significant differences (study $1: \mathrm{F}=7.37, \mathrm{df}=5,30, P=$ 0.0001 ; study $2: \mathrm{F}=5.28$, $\mathrm{df}=5,30, P=$ $0.0014)$ in $B$. occiduus damage ratings and

Table 1. Zoysiagrass resistance to Blissus occiduus.

\begin{tabular}{|c|c|c|c|c|c|}
\hline \multirow[b]{2}{*}{ Zoysia cultivars } & \multicolumn{2}{|c|}{ Mean damage $^{z}$} & \multicolumn{2}{|c|}{ Mean no. of chinch bugs ${ }^{y}$} & \multirow[b]{2}{*}{ Resistance rating ${ }^{x}$} \\
\hline & Study 1 & Study 2 & Study 1 & Study 2 & \\
\hline $378^{\mathrm{w}}$ & $4.0 \mathrm{a}$ & $4.5 \mathrm{a}$ & $39.2 \mathrm{ab}$ & $61.3 \mathrm{a}$ & $\mathrm{HS}$ \\
\hline Zenith & $4.0 \mathrm{a}$ & $3.5 \mathrm{bcd}$ & $14.5 \mathrm{~cd}$ & $11.0 \mathrm{~b}$ & HS-MS \\
\hline Meyer & $3.8 \mathrm{ab}$ & $4.0 \mathrm{abc}$ & $5.0 \mathrm{~cd}$ & $3.8 \mathrm{~b}$ & HS-MS \\
\hline Crowne & $3.2 \mathrm{c}$ & $4.2 \mathrm{ab}$ & $23.8 \mathrm{bc}$ & $24.5 \mathrm{~b}$ & HS-MS \\
\hline DeAnza $^{v}$ & $3.3 \mathrm{bc}$ & - & $4.5 \mathrm{~cd}$ & - & MS \\
\hline El Toro & $2.8 \mathrm{~cd}$ & $3.3 \mathrm{~cd}$ & $36.5 \mathrm{ab}$ & $16.8 \mathrm{~b}$ & MR-MS \\
\hline Royal & $2.8 \mathrm{~cd}$ & $3.0 \mathrm{de}$ & $1.2 \mathrm{~d}$ & $4.0 \mathrm{~b}$ & MR-MS \\
\hline Cavalier & $2.5 \mathrm{~d}$ & $3.2 \mathrm{~cd}$ & $2.8 \mathrm{~d}$ & $2.3 \mathrm{~b}$ & MR-MS \\
\hline Palisades & $2.3 \mathrm{de}$ & $3.0 \mathrm{de}$ & $4.8 \mathrm{~cd}$ & $7.0 \mathrm{~b}$ & MR-MS \\
\hline Prestige $^{u}$ & $2.5 \mathrm{~d}$ & $2.8 \mathrm{de}$ & $56.5 \mathrm{a}$ & $72.3 \mathrm{a}$ & MR \\
\hline Diamond & $2.3 \mathrm{de}$ & $2.8 \mathrm{de}$ & $5.0 \mathrm{~cd}$ & $2.3 \mathrm{~b}$ & MR \\
\hline Zoro & $2.3 \mathrm{de}$ & $2.2 \mathrm{ef}$ & $7.3 \mathrm{~cd}$ & $8.8 \mathrm{~b}$ & MR \\
\hline Emerald & $1.8 \mathrm{e}$ & $1.8 \mathrm{f}$ & $1.8 \mathrm{~d}$ & $1.5 \mathrm{~b}$ & MR \\
\hline
\end{tabular}

${ }^{\mathrm{z}} 1,10 \%$ or less of leaf area with reddish discoloration; $2,11 \%$ to $30 \%$ of leaf area with reddish discoloration; $3,31 \%$ to $50 \%$ of leaf area with reddish discoloration; $4,51 \%$ to $70 \%$ of leaf area with reddish or yellowing discoloration; $5,71 \%$ or more of leaf area with severe discoloration or dead tissue (Heng-Moss et al., 2002). Study $1 \mathrm{sE}, 0.32$; study $2 \mathrm{sE}, 0.34$.

${ }^{y}$ Mean number of chinch bugs per cone-tainer at harvest. Study $1 \mathrm{SE}, 10.2$; study $2 \mathrm{SE}, 15.5$.

${ }^{x} \mathrm{HR}$, highly resistant; HS, highly susceptible; MR, moderately resistant; MS, moderately susceptible (Heng-Moss et al., 2002).

w‘378', susceptible buffalograss (Heng-Moss et al., 2003)

'DeAnza' not included in study 2 because of insufficient plant material.

"'Prestige', resistant buffalograss (Heng-Moss et al., 2003).

Means within the same column followed by the same letter are not significantly different $(P>0.05$, Fisher's LSD test). 
Table 2. Bermudagrass resistance to Blissus occiduus.

\begin{tabular}{|c|c|c|c|c|c|}
\hline \multirow{2}{*}{$\begin{array}{l}\text { Bermudagrass } \\
\text { cultivars }\end{array}$} & \multicolumn{2}{|c|}{ Mean damage ${ }^{z}$} & \multicolumn{2}{|c|}{ Mean no. of chinch bugs ${ }^{y}$} & \multirow{2}{*}{$\begin{array}{c}\text { Resistance } \\
\text { rating }^{\mathrm{x}}\end{array}$} \\
\hline & Study 1 & Study 2 & Study 1 & Study 2 & \\
\hline $378^{w}$ & $4.0 \mathrm{a}$ & $4.5 \mathrm{a}$ & $39.2 \mathrm{a}$ & $61.3 \mathrm{a}$ & HS \\
\hline Tifway & $3.2 \mathrm{~b}$ & $3.5 \mathrm{~b}$ & $9.8 \mathrm{~b}$ & $14.8 \mathrm{~b}$ & MS \\
\hline Tifsport & $3.0 \mathrm{~b}$ & $3.5 \mathrm{~b}$ & $2.5 \mathrm{~b}$ & $5.8 \mathrm{~b}$ & MS \\
\hline Jackpot & $2.8 \mathrm{~b}$ & $3.0 \mathrm{bc}$ & $0.8 \mathrm{~b}$ & $1.0 \mathrm{~b}$ & MR-MS \\
\hline Prestige $^{\mathrm{v}}$ & $2.5 \mathrm{~b}$ & $2.8 \mathrm{bc}$ & $56.5 \mathrm{a}$ & $72.3 \mathrm{a}$ & MR \\
\hline Mini Verde & $1.7 \mathrm{c}$ & $2.5 \mathrm{c}$ & $2.8 \mathrm{~b}$ & $1.2 \mathrm{~b}$ & MR \\
\hline
\end{tabular}

$\mathrm{z} 1,10 \%$ or less of leaf area with reddish discoloration; $2,11 \%$ to $30 \%$ of leaf area with reddish discoloration; $3,31 \%$ to $50 \%$ of leaf area with reddish discoloration; $4,51 \%$ to $70 \%$ of leaf area with reddish or yellowing discoloration; $5,71 \%$ or more of leaf area with severe discoloration or dead tissue (Heng-Moss et al., 2002). Study 1 SE, 0.4; study 2 SE, 0.43.

${ }^{y}$ Mean number of chinch bugs per cone-tainer at harvest. Study $1 \mathrm{SE}, 9.0$; study $2 \mathrm{SE}, 21.5$.

${ }^{\mathrm{x}} \mathrm{HS}$, highly susceptible; MR, moderately resistant; MS, moderately susceptible (Heng-Moss et al., 2002).

w'378', susceptible buffalograss.

"Prestige', resistant buffalograss.

Means within the same column followed by the same letter are not significantly different $(\mathrm{P}>0.05$, Fisher's LSD test).

the number of $B$. occiduus (study 1: $\mathrm{F}=$ 13.55 , df $=5,30, P=0.0001$; study $2: \mathrm{F}=$ $4.45, \mathrm{df}=5,30, P=0.0038$ ) remaining on the grasses at harvest were detected among the turfgrass species evaluated in studies 1 and 2 (Table 2). Of the bermudagrasses evaluated, none were as susceptible to $B$. occiduus as the susceptible buffalograss cultivar 378 . The bermudagrasses 'Tifway' and 'Tifsport' were moderately susceptible, with mean damage ratings of 3.2 and 3.0 in study 1 , respectively, and 3.5 and 3.5 in study 2 , respectively. 'Jackpot' was moderately resistant to moderately susceptible, with damage ratings of 2.8 and 3.0 in studies 1 and 2 respectively. 'Mini Verde' was characterized as moderately resistant (damage ratings of 1.7 and 2.5 respectively) and was comparable with the resistant buffalograss 'Prestige'. All bermudagrasses tested had significantly fewer chinch bugs remaining at harvest than 'Prestige', indicating they may not be good reproductive hosts for $B$. occiduus (Table 2). These results support the findings of Eickhoff et al. (2004). 'Mini Verde' was the only bermudagrass to have a lower damage rating than the chinch bug-resistant buffalograss 'Prestige', indicating this cultivar is also resistant to B. occiduus.

\section{Discussion}

Based on turfgrass damage ratings, the zoysiagrasses 'Diamond', 'Zoro', and 'Emerald', and the bermudagrass 'Mini Verde' were characterized as moderately resistant to $B$. occiduus. These zoysiagrass and bermudagrass cultivars had comparable damage ratings with the resistant buffalograss 'Prestige'. All the grasses categorized as moderately resistant had significantly fewer chinch bugs present at the time of harvest than the resistant and susceptible buffalograsses. This suggests that antibiosis or antixenosis may be responsible for their resistance. The zoysiagrasses 'Zenith', 'Meyer', and 'Crowne' were highly to moderately susceptible to B. occiduus feeding, whereas 'DeAnza' and the bermudagrasses 'Tifway' and 'Tifsport' were characterized as moderately susceptible. Furthermore, several of these grasses
('Meyer', 'Zenith', 'DeAnza', 'Tifway', and 'Tifsport') had relatively low chinch bug numbers remaining at harvest, indicating that even at low infestation levels, B. occiduus can cause significant damage to these grasses.

It is interesting to note that 'Meyer' zoysiagrass did not have high numbers of $B$. occiduus remaining at harvest. 'Meyer' is widely grown in southeastern Nebraska and is commonly infested with $B$. occiduus in urban landscapes. The high level of damage observed in 'Meyer', despite low numbers of chinch bugs, supports field observations that 'Meyer' is highly susceptible to B. occiduus feeding.

Prior research conducted under both laboratory and field conditions has identified numerous cool- and warm-season turfgrasses with resistance to B.l. leucopterus, B.l. hirtus, B. insularis, and B. occiduus (Anderson et al., 2006; Baker et al., 1981; Gulsen et al., 2004; Heng-Moss et al., 2002; Mathais et al., 1990; Ratcliffe, 1982; Reinert and Dudeck, 1974). This research represents the first report of zoysiagrass and bermudagrass resistance to B. occiduus. In addition, this research documents the genetic variation in zoysiagrass and bermudagrass germplasm, suggesting the potential to improve chinch bug resistance among these important turfgrasses.

\section{Literature Cited}

Ahmad, T.R., K.P. Pruess, and S.D. Kindler. 1984. Non-crop grasses as hosts for the chinch bug, Blissus leucopterus leucopterus (Say) (Hemiptera: Lygaeidae). J. Kans. Entomol. Soc. 57:17-20.

Anderson, W.G., T.M. Heng-Moss, and F.P. Baxendale. 2006. Evaluation of cool- and warm-season grasses for resistance to multiple chinch bug (Hemiptera: Blissidae) species. J. Econ. Entomol. 99:203-211.

Baker, P.B., R.H. Ratcliffe, and A.L. Steinhauer. 1981. Tolerance to hairy chinch bug (Blissus leucopterus) feeding in Kentucky bluegrass (Poa pratensis). Environ. Entomol. 10:153-157.

Baxendale, F.P., T.M. Heng-Moss, and T.P. Riordan. 1999. Blissus occiduus (Hemiptera: Lygaeidae): A chinch bug pest new to buffalograss turf. J. Econ. Entomol. 92:1172-1176.

Bird, R.D. and A.V. Mitchner. 1950. Insects of the season 1949 in Manitoba. Can. Insect Pest Rev. $28: 41$.
Braman, S.K., R.R. Duncan, W.W. Hanna, and M.C. Engelke. 2004. Turfgrass species and cultivar influences on survival and parasitism of fall armyworm. J. Econ. Entomol. 97:19931998.

Braman, S.K., A.F. Pendley, R.N. Carrow, and M.C. Engelke. 1994. Potential resistance in zoysiagrasses to tawny mole crickets (Orthoptera: Gryllotalpidae). Fla. Entomol. 77:301-305.

Eickhoff, T.E., F.P. Baxendale, T.M. Heng-Moss, and E.E. Blankenship. 2004. Turfgrass, crop and weed hosts Blissus occiduus (Hemiptera: Lygaeidae). J. Econ. Entomol. 97:67-73.

Eickhoff, T.E., T.M. Heng-Moss, and F.P. Baxendale. 2006. Host preference of the chinch bug, Blissus occiduus. J. Insect Sci. 6(7):6.

Farstad, C.W. and A. Staff. 1951. Insects of the season in Alberta, 1950. Can. Insect Pest Rev. 29:18.

Ferris, G.F. 1920. Insects of economic importance in the cape region of lower California, Mexico. J. Econ. Entomol. 13:463-467.

Frank, K.W., R.E. Gaussoin, T.P. Riordan, R.C. Shearman, J.D. Fry, E.D. Miltner, and P.G. Johnson. 2004. Nitrogen rate and mowing height effects of turf-type buffalograss. Crop Sci. 44:1615-1621.

Gulsen, O., T.M. Heng-Moss, R. Shearman, P.S. Baenziger, D. Lee, and F.P. Baxendale. 2004. Buffalograss germplasm resistance to Blissus occiduus (Hemiptera: Lygaeidae). J. Econ. Entomol. 96:2101-2105.

Heng-Moss, T.M., F.P. Baxendale, T.P. Riordan, and J.E. Foster. 2002. Evaluation of buffalograss germplasm for resistance to Blissus occiduus turf. J. Econ. Entomol. 95:1054-1058.

Heng-Moss, T.M., F.P. Baxendale, T.P. Riordan, L.J. Young, and K. Lee. 2003. Chinch bugresistant buffalograss: An investigation of tolerance, antixenosis and antibiosis. J. Econ. Entomol. 96:1942-1951.

Lynch, R.E., S. Some, I. Dicko, H.D. Wells, and W.G. Monson. 1987. Chinch bug damage to bermudagrass. J. Entomol Sci. 22:153-158.

Mathais, J.K., R.H. Ratcliffe, and J.L. Hellman. 1990. Association of an endophytic fungus in perennial ryegrass and resistance to the hairy chinch bug (Hemiptera: Lygaeidae). J. Econ. Entomol. 83:1640-1646.

Ratcliffe, R.H. 1982. Evaluation of cool-season turfgrass for resistance to the hairy chinch bug, p. 13-18. In: H.D. Niemczyk and B.G. Joyner (eds.). Advances in turfgrass entomology. Hammer Graphics, Piqua, Ohio.

Reinert, J.A. and A.E. Dudeck. 1974. Southern chinch bug resistance in St. Augustinegrass. J. Econ. Entomol. 67:275-277.

Reinert, J.A., M.C. Engelke, and S. Morton. 1993. Zoysiagrass resistance to the zoysiagrass mite, Eriophyes zoysiae (Acari: Eriophyidae). Int Turfgrass Soc. Res. J. 7:349-352.

Reinert, J.A., P.R. Heller, and R.L. Crocker. 1995 Chinch bugs, p. 38-42. In: R.L. Brandenburg and M.G. Villani (eds.). Handbook of turfgrass pests. Entomological Society of America, Landham, Md.

Reinert, J.A., C.M. Taliaferro, M.C. Engelke, J.A. McAfee, and R.E. Myers. 2005. Fall armyworm (Spodoptera frugiperda) resistance among bermudagrass (Cynodon) genotypes and cultivars. Int. Turfgrass Soc. Res. J. 10: 761-766.

Slater, J.A. 1964. A catalogue of the Lygaeidae of the world. University of Connecticut, Storrs, Conn.

Southwood, T.R.E. 1978. Ecological methods, Halstad, N.Y.

Vittum, P.J., M.G. Villani, and H. Tashiro. 1999. Turfgrass insects of the United States and Canada. Cornell University Press, Ithaca, N.Y. 